\title{
JEZZYK JAKO WYZWANIE. O STRATEGIACH PISARSKICH ANNY LANGFUS I PIOTRA RAWICZA
}

\section{Anna CIARKOWSKA (Uniwersytet Lódzki)}

Dla przedstawicieli diasporycznej, rozsianej po świecie społeczności żydowskiej, wybór języka ekspresji twórczej jest nieoczywisty — to zawsze pewnego rodzaju tożsamościowa deklaracja, która sytuuje pisarza w konkretnym obiegu komunikacyjnym i naznacza jego relację z tradycją żydowską. Sytuując w jednej przestrzeni, jednocześnie wyklucza go z innej, dlatego też można stwierdzić, że pisarstwo żydowskie zawsze funkcjonuje na jakimś pograniczu i naznaczone jest pewnego rodzaju obcością. Jedną z cech takiego funkcjonowania ,pomiędzy” jest konieczność nieustannego definiowania swojego miejsca, potwierdzania współrzędnych i lokowania się względem centrum, czy też „centrów”, jeśli uznać za jeden punkt odniesienia kulturę „ojczyzny”, za drugi zaś — kulturę żydowską.

W wypadku pisarzy tworzących po Szoa, cały ten układ odniesienia zdaje się tracić ważność, obcość staje się immanentna, co prowadzi do zniesienia opozycji „swój” „obcy”.

Autor poruszający temat Holocaustu — pisze Imre Kertész — zawsze i niezależnie od języka, w jakim pisze, jest duchowym uchodźcą, który w zawsze obcym dla siebie języku prosi o azyl ${ }^{1}$.

Najsilniej wstrząs utraty języka przeżyli żydowscy emigranci, których problem ten dotykał podwójnie - metaforyczna niemoc zaświadczania o przekraczającej granice wyobraźni katastrofie Szoa splatała się z zupełnie realnym doświadczeniem niemocy porozumienia się w obcym języku. Konieczne stało się wypracowanie strategii pisania — poruszania się w kruchej materii języka „pożyczonego”, „nie dla siebie przeznaczonego",

\footnotetext{
${ }^{1}$ I. Kertész, Język na wygnaniu, przeł. E. Sobolewska, Warszawa 2004, s. 184

${ }^{2}$ Tamże, s. 181
} 
Owe strategie i praktyki pisarskie są rozmaite, wszystkie jednak oscylują między dwoma biegunami - między całkowitym zakorzenieniem a całkowitym wykorzenieniem. Na tych właśnie biegunach znaleźli się żydowscy pisarze polskiego pochodzenia, tworzący we Francji - Anna Langfus i Piotr Rawicz. Łączyło ich bardzo wiele: oboje wywodzili się ze środowiska zamożnych, zasymilowanych Żydów, mieli podobny bagaż wojennych doświadczeń, w tym samym momencie wyjechali z Polski i niemal równocześnie wydali dwie ważne dla francuskiego czytelnika powieści o Zagładzie. Zarazem dzieliło ich postrzeganie roli pisarza-świadka, a także „bycia-w-języku”, co bezpośrednio przekładało się na ich, bardzo odmienną formalnie, twórczość literacką.

Poszerzone ujęcie problemu wyczerpania języka po Szoa pozwala na głębszą analizę strategii zmiany języka ekspresji żydowskich pisarzy-emigrantów i dostrzeżenie w tym wyborze lingwistycznym realizacji szerszego projektu tożsamościowego. W wypadku Langfus i Rawicza dwie strategie, dwa bieguny językowej asymilacji, zbiegają się w jednym wspólnym punkcie, jakim jest język francuski - językwyzwanie.

\section{Na krawędzi mowy, na krawędzi języka}

Zagłada podważyła istniejące systemy reprezentacji, czyniąc język niewystarczającym i postludzkim - niezdolnym do ekspresji ludzkiego doświadczenia ${ }^{3}$. O paraliżu języka po Szoa można mówić na co najmniej dwóch poziomach. Na poziomie pierwszym, metafizyczny, uderza on w fantazmat całości, pełni, porządku - fundament Katastrofy. Każda opowieść ma przecież pretensje do bycia całością, nie dość, że zamkniętą w sztywne ramy systemu językowego, to jeszcze wyrażającą świat w pełni, wygładzającą i uspójniającą jego obraz.

Drugi poziom „paraliżu” wiąże się z semantycznym wyczerpaniem słów. Żadne bowiem słowo, które istniało przed Auschwitz, nie pokrywa tamtego doświadczenia. Według Prima Leviego, gdyby lagry istniały dłużej, musiałby narodzić się nowy język i tylko w nim byłyby możliwe do wypowiedzenia słowa, które dziś nie pokrywają doświadczenia ocalonych: głód, zimno, strach ${ }^{4}$.

To, co naziści uczynili Żydom, było nie do wypowiedzenia - pisze z kolei Theodor W.

Adorno w Minima moralia - języki nie miały na to słów, bo w obliczu planowości, systematyczności i totalności nawet „masowy mord” brzmiałby jak cytat $\mathrm{z}$ dawnych dobrych czasów nauczyciela z Degerloch"

Do tej „podwójnej” niemożności — tworzenia w nowym, totalnym języku i jednocześnie w języku starym i niewystarczającym — dodać należy i trzecią niemożność: milczenie. Wbrew rozpowszechnionym interpretacjom, inspirowanym zbyt powierzchowną lekturą dzieł Adorna, filozof ten nie wysuwał postulatu milczenia, bo „trwające cierpienie ma prawo do ekspresji, jak maltretowany do krzyku"6. Milczenie byłoby czystą tautologią, powtórzeniem nazistowskiego gestu, cichym nań przyzwoleniem? Adorno postuluje więc takie pisanie, które celowałoby w rozbicie fantazmatu całości,

${ }^{3}$ A. Ubertowska, Świadectwo, trauma, głos. Literackie reprezentacje Holocaustu, Kraków 2007, s. 30.

${ }^{4}$ Z. Waxman, Writing the Holocaust: identity, testimony, representation, London 2008, s. 180.

${ }^{5}$ T.W. Adorno, Minima moralia, przeł. M. Łukasiewicz, Kraków 2009, s. 303.

${ }^{6}$ Dalej w tym fragmencie Adorno odnosi się bezpośrednio do postulatu milczenia: „dlatego raczej mylny byłby sąd, że po Oświęcimiu nie można już napisać żadnego wiersza"; T.W. Adorno, Dialektyka negatywna, przeł. K. Krzemieniowa, Warszawa 1987, s. 509.

${ }^{7} \mathrm{Z}$. Waxman, Writing the Holocaust, s. 178. 
by wśród „zgruchotanych fundamentów poszukiwać nowych form”. Zadaniem pisarskim byłoby zatem zapisanie stanu rozpadu, wyczerpania języka, pogłębienie rozpadu mowy, uwydatnienie jej fragmentaryczności, zamiast scalania w pozorną całość opowieści. Sarah Kofman postuluje pisanie w języku „bezsilnym”:

Trzeba mówić bez mocy: tak, by język, zbyt silny, suweren, nie zawładnął najbardziej aporetyczną sytuacją, absolutną niemocą i smutkiem, by nie zamknął tego w jasności i radości dnia ${ }^{9}$.

Słowa mają być „,przyduszone”, czy też, jak u Giorgio Agambena, mają mieć „dźwięk

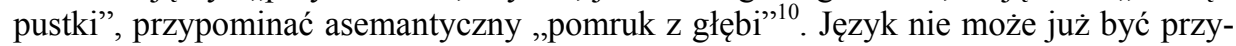
padkowy, lekki, jest ciężki od historii, jaka się w nim rozegrała, staje się brzemieniem dla pisarza-Syzyfa ${ }^{11}$.

\section{Strategie mówienia}

Postulaty teoretyczne są zatem jasne: pisać na zgliszczach, na krawędzi, w „rozpadającym się języku umarłych”, poruszać się na granicy wypowiedzianego, wymykać się systemowi, pokusie całości i pełni. Przeniesienie tych postulatów na grunt praktyki pisarskiej wymagało podjęcia szeregu decyzji, bardzo konkretnych, podstawowych, poczynając od najbardziej, wydawałoby się, naturalnej kwestii: w jakim języku pisać? Ścieżki są dwie: eksplorowanie na nowo języka ojczystego, szukanie w nim semantycznych pęknięć i uskoków lub też wejście w obszar języka zupełnie nowego, obcego, co stało się udziałem większości żydowskich emigrantów.

Zmiana języka emigrantów wydawać by się mogła czymś zupełnie naturalnym i powodowanym względami praktycznymi. Nowy kraj, nowa kultura, wreszcie nowi czytelnicy — wejście w obieg literacki było możliwe tylko w języku większości. Taka odpowiedź byłaby jednak zbyt prosta i pochopna. Jeśli bowiem prześledzimy losy poszczególnych pisarzy-emigrantów, okaże się, że zmiana języka wcale nie była tak oczywista i jednoznaczna, a strategii przemiany było co najmniej kilka: począwszy od cytowanego wcześniej Kertésza, który pisał po węgiersku, chociaż przebywał właściwie na stałe w Berlinie, poprzez Eliego Wiesela, który zadebiutował w języku jidysz powieścią Un di welt hot geszwign, przetłumaczoną przez samego autora na język francuski jako La Nuit, aż po wspomnianych pisarzy o polskich korzeniach — Rawicza i Langfus, którzy pisali od razu po francusku. Przykłady rozmaitych ścieżek językowych emigrantów można by mnożyć: Jean Améry, Jorge Semprún, Danilo Kiš, co utwierdza tylko w przekonaniu, że warto odejść od prostego schematu: emigracja zmiana języka. Można bowiem dostrzec procesualność, złożoność tej decyzji, rozmaite możliwe ścieżki i praktyki pisarskie z tym związane.

\section{Anna Langfus - zakorzenienie}

Urodzona w 1920 r. w rodzinie zasymilowanych lubelskich Żydów, Anna Langfus (z domu Szternfinkiel) podczas wojny przebywała w gettach w Lublinie i w Warszawie; aresztowana jako Polka, była torturowana i przetrzymywana w więzieniu w Płoń-

\footnotetext{
${ }^{8}$ A. Ubertowska, Świadectwo, s. 37.

9 S. Kofman, Paroles suffoquées, Paryż 1986, s. 16. Jeżeli nie podano inaczej, wszystkie thumaczenia pochodzą od autorki artykułu.

${ }^{10}$ G. Agamben, Co zostaje z Auschwitz: archiwum i świadek, przeł. S. Królak, Warszawa 2008, s. 36-39.

${ }^{11}$ T. W. Adorno, Minima, s. 266, 303.
} 
sku. Wyemigrowała do Paryża w roku 1946 r. za namową radcy ambasady francuskiej $^{12}$. Jej kariera literacka rozpoczyna się w 1953 r., kiedy to napisała swoją pierwszą sztukę teatralną - Les Lépreux, wystawioną trzy lata później przez Sachę Pitoëffa. Od roku 1958 r. pracowała nad swoją pierwszą powieścią, która w 1960 r. ukazała się nakładem wydawnictwa Gallimard pod tytułem Le Sel et le soufre ${ }^{13}$. Dwa lata później wydała Les Bagages de sable, które w listopadzie 1962 r. nagrodzone zostały prestiżową Prix Goncourt.

Powieści te, szczególnie pierwsza, są osnute na kanwie autobiograficznej. „Pisząc, próbowałam uwolnić się od zbyt trudnego osobistego doświadczenia” - mówiła autorka przed publicznością, zgromadzoną na kongresie WIZO w marcu $1963 \mathrm{r}$.

[...] być może byłam na tyle naiwna, że miałam nadzieję, iż ciężar książki wystarczy do ponownego ustanowienia równowagi między przeszłością a teraźniejszością. Później zdałam sobie sprawę, jak bardzo się wówczas łudziłam, myśląc [...], że będę wolna i zajmę się innymi sprawami, a przede wszystkim, że będę pisała powieści, które będę mogła uznać za owoc czystej wyobraźni ${ }^{14}$.

Nigdy, co sama dalej przyznaje, nie udało jej się przejść do pisania czystej fikcji. Podobnie nie weszła nigdy w obszar literackich eksperymentów, awangardowych rozwiązań formalnych czy fabularnych. Więcej nawet, jak pisze Anne Dayan-Rosenman, mamy u Langfus do czynienia z językiem „skrajnie klasycznym”, zaś za cechę charakterystyczną jej pisarstwa, chociaż trudno powiedzieć, że szczególnie wyróżniającą, uznać można ,przelewanie się zdań” — „brak znaków przystankowych, całe paragrafy następujące po sobie" ${ }^{\prime 15}$. Francuska badaczka dostrzega pewną oryginalność stylu rodzaj rytmu, choć trudno uchwycić, na czym miałaby polegać owa wyjątkowość. Nie ma w tym francuskim tekście, pisanym przez Polkę, śladu obcości czy niezwykłości, wynikającej z bilingwizmu właśnie.

Anna Langfus obrała bowiem strategię językowej mimikry, wypleniając ze swojej twórczości literackiej wszelkie ślady obcości. Ten ,projekt” całkowitego zakorzenienia się we francuszczyźnie przekładał się nie tylko na praktykę pisarską, ale na całe życie pisarki i tworzoną przez nią autokreację, opartą na micie pisarki „wykorzenionej”, która wrasta w trudzie w grunt nowego języka. „Anna Langfus, Goncourt 1962, to łobuz, który nauczył się francuskiego po wojnie w sierocińcu"16 — brzmiał lead obszernego artykułu o autorce, nagrodzonej najbardziej prestiżową nagrodą literacką we Francji. Tymczasem znała ona jeszcze przed wojną język francuski w stopniu biegłym $^{17}$.

${ }^{12}$ J.-Y. Potel, Kalendarium życia i twórczości Anny Langfus (1920-1966), przeł. A. Zachariewicz, Scriptores $2013 \mathrm{nr}$ 34, s. 42.

${ }^{13}$ Powieść została wydana w Polsce w 2008 r. w thumaczeniu Hanny Abramowicz pod tytułem Skazana na życie. s. 167

${ }^{14}$ A. Langfus, Krzyku się nie wydrukuje, przeł. H. Abramowicz, Scriptores 2013 nr 34,

15 A. Dayan-Rosenman, Anna Langfus - pamięć/zapomnienie, przeł. A. Zachariewicz, s. $302-303$.

${ }^{16}$ C. Marlaux, Ostra - rozmowa z Anna Langfus, przeł. H. Abramowicz, s. 25.

${ }^{17}$ Trzeba podkreślić, że nie tylko uczyła się języka jeszcze w gimnazjum im. Unii Lubelskiej, gdzie uchodziła za bardzo uzdolnioną łacinniczkę i romanistkę, ale także przez rok studiowała $\mathrm{w}$ belgijskim Verviers, gdzie słynęła $\mathrm{z}$ bardzo dobrej znajomości języka i doskonałych wyników w nauce (wszystkie zajęcia odbywały się po francusku); zob. J.-Y. Potel, Les Disparitions d'Anna Langfus, Paris 2014, s. 45-49. 
Wniknięcie we francuszczyznę wiązało się z zupełnym odcięciem innych języków — polskiego i żydowskiego. Langfus znała jidysz najprawdopodobniej słabo i był to dla niej, jak wspomina przyjaciel pisarki Maurice Fickelson, język zabobonu, przesądu, który posiadał rodzaj mocy odwracającej zły los, co zapewne miało związek z wieczornym rytuałem czytania modlitw w domu Szternfinkielów. Fickelson dodaje, że zdarzało się jej niekiedy w obecności Francuzów mówić w tym języku, używając go niczym szyfru znanego tylko nielicznym ${ }^{18}$.

Jeśli zaś chodzi o język polski, to w zasadzie po przyjeździe do Francji przestała go używać. Do tego stopnia, że rozmawiając ze swoim mężem, polskim Żydem, często posługiwała się francuszczyzną, a ich córka, Maria, nie znała języka ojczystego rodziców. Rzadko zdarzało jej się mówić po polsku. Przeprowadzający z pisarką wywiad dla czasopisma „Kamena”, Tadeusz Domański notuje:

Teraz Anna Langfus mówi po polsku. Powoli, zastanawiając się nad doborem słów. Czuje się, że nie ma tego języka w codziennym użyciu, ale polszczyzna jej jest ładna i bogata 19 .

Zawsze podkreślała zresztą swoje uwielbienie dla polskiej literatury, szczególnie dla Juliusza Słowackiego. Wspomina o tym także i Fickelson, dodając:

Mówiła czasem o swoich uczuciach do języka polskiego, o fizycznym wręcz odczuciu, fizycznym związku z tym językiem. Jak mówiła, związku na płaszczyźnie zmysłowej... ${ }^{20}$.

\section{Piotr Rawicz - wykorzenienie}

Piotr Rawicz urodził się w 1919 r. we Lwowie, również w zasymilowanej rodzinie żydowskiej. W czasie wojny przebywał w getcie lwowskim, z którego uciekł na tzw. „,aryjskich papierach” i jako Polak był więziony w Auschwitz i w Leitmeritz. W 1945 r. zamieszkał w Krakowie, gdzie podjął studia orientalistyczne, rozpoczęte na Uniwersytecie Jana Kazimierza we Lwowie. Decyzję o wyjeździe Rawicz podjął w 1946 r. i, otrzymawszy stypendium rządu francuskiego, mógł w 1947 r. wyjechać do Paryża. Na pisanie powieści Le Sang $d u$ ciel $^{21}$ poświęcił dwa lata. Została ona opublikowana przez wydawnictwo Gallimard w $1961 \mathrm{r}$.

Powieść Rawicza, zgodnie z przewidywaniem Heleny Wolff, rekomendującej książkę do anglojęzycznego wydania, nie odniosła sukcesu czytelniczego, ale wzbudziła szerokie zainteresowanie krytyków i badaczy ${ }^{22}$. Stało się tak przede wszystkim ze względu na skomplikowaną, hybrydyczną strukturę tekstu, który, choć oparty jest na doświadczeniach autora, zdecydowanie wyłamuje się z klasycznych ram powieściowych. O jego niezwykłości stanowi nie tylko „rozbita” struktura fabularna, ale przede wszystkim rodzaj wielojęzyczności, wyczuwalnej pod warstwą francuszczyzny ${ }^{23}$. Józef Czapski w dyskusji na temat pisarzy-emigrantów stwierdził:

18 J.-Y. Potel, Rozmowa z Maurice'em Fickelsonem, przeł. H. Abramowicz, Scriptores 2012 nr 34, s. 129.

${ }_{19}^{19}$ T. Domański, Paryżanka z Lublina, Kamena 1962 nr 23, s. 126; przedruk w Scriptores 2013 nr 34, s. 360-362.

${ }^{20}$ Tamże, s. 126

${ }^{21}$ Powieść ta została wydana w Polsce w 2003 r. w tłumaczeniu Andrzeja Sochy pod tytułem Krew nieba.

${ }^{22}$ H. Mitgang, Profiles: Imprint. Helen Wolff, The New Yorker, 2.09.1982, s. 64.

${ }^{23}$ Por.: P. Sadkowski, Proza Piotra Rawicza jako przyktad pisarstwa francusko-żydowskiego w świetle (post)kafkowskich koncepcji , literatury mniejszej” i zjawiska „,nadświadomości 
[...] jestem prawie wściekły, że jest ona [tj. powieść — przyp. A. C.] napisana po francusku, ponieważ całość, a wręcz materia powieści sugerują, że książka ta powinna być napisana amalgamatem trzech języków, polskiego, żydowskiego i ukraińskiego. Mogłoby to wydać nowego Joyce'a Europy Centralnej ${ }^{24}$.

Przytakiwał mu Konstanty Jeleński, mówiąc, że język Rawicza jest ,językiem imaginacyjnym, wyobraźniowym, niesie sam w sobie ekwiwalent ziemi ojczystej pisarza"25. To właśnie tę trudną do uchwycenia kakofoniczność, sytuującą tekst na granicy poprawności językowej, a nawet rozumienia, należy uznać za cechę wyjątkową, wyróżniającą utwór na tle całej literatury Szoa.

W odróżnieniu zatem od strategii, obranej przez Langfus, Rawicz nie zakorzenił się w języku francuskim, więcej nawet — pielęgnował w sobie stan wykorzenienia poprzez „rozbijanie” materii językowej. Znając jidysz, hebrajski, niemiecki, rosyjski, ukraiński, a także hindi, sanskryt, turecki i arabski, Rawicz zręcznie wymykał się wszelkim językowym kwalifikacjom, poruszając się zawsze na krawędzi mowy, w szczelinie między językami, czego najlepszym i najpełniejszym odbiciem są zachowane notatki pisarza ${ }^{26}$. Jego francuszczyzna nie stała na najwyższym poziomie, teksty dla literackiego dodatku „Le Monde” przechodziły zawsze rozliczne korekty, a i tekst powieści, jak można przypuszczać, był wielokrotnie poprawiany. Wszystko jednak wskazuje na to, że pisał od razu w języku obcym, z błędami i, jak można przypuszczać, $\mathrm{z}$ wielkim trudem.

W tym językowym amalgamacie szczególne miejsce zajmowały języki „lwowskiej ulicy": jidysz, polski, rosyjski. O tych językach mówi podobnie jak cytowany wcześniej Fickelson ,na poziomie zmysłów”:

Żeby nie wyjść na nieuprzejmych wobec innych gości, naśladowaliśmy [z Ephraimem Sevelą] rosyjski pomieszany z kilkoma wybornymi wyrażeniami w jidysz. System odniesień żydowsko-słowiańskich, ten lingwistyczny koktajl tak bliski mojemu sercu i przyjemny dla mojego podniebienia, sprawił, że szybko nawiązała się między nami nić porozumienia ${ }^{27}$.

Rawicz często posługuje się pewnego rodzaju językowym „stopem” — rosyjsko-polsko-słowiańskim, broniąc się niejako przed zamknięciem w języku, który jest zawsze ,jak obóz koncentracyjny, drugi stopień więzienia [...]"28 , a jedyną przed nim ucieczką jest pielęgnowanie stanu językowego wykorzenienia, lingwistycznej atopii.

\section{Język jako wyzwanie}

W książce Zagłada i pamięć, Barbara Engelking zadaje kluczowe pytanie:

czy [ocalali] mogli znaleźć w tych językach [których nauczyli się dopiero po wojnie]

językowej”, [w:] „Literatury mniejsze” Europy romańskiej, red. M. Loba, B. Luczak, A. Gregori, Poznań 2012, s. 77-85.

${ }^{24}$ K. Jeleński, P. Rawicz, J. Czapski i in., Pisarz na wygnaniu a styl, przeł. I. Burzacka, Archiwum Emigracji. Studia — Szkice — Dokumenty 1999 z. 2, s. 27.

${ }^{25}$ K. Jeleński przeciwstawia język Rawicza stylowi Emila Ciorana, który stał się, jego zdaniem, pisarzem francuskim ,w pełnym tego słowa znaczeniu”; zob. tamże, s. 24.

${ }^{26}$ Zob.: A. Ciarkowska, Pisanie , na zgliszczach” języka, Midrasz 2014 nr 5 (181), s. 47-52.

${ }^{27}$ P. Rawicz, Préface, [w:] E. Sevela, Légendes de la rue des invalides, Paris 1992, s. 5.

${ }^{28}$ Tenże, Solitude Juive dans la création litteraire, [w:] Solitude d'Israël: données et débats I XV Colloque d'intellectuels juifs de langue française ; organisé par la Section française du Congrès juif mondial, red. J. Halpérin, G. Levitte, Paris 1975 , s. 73. 
słowa opisujące rzeczywistość, o której myśleli w innym języku? Czy byli w stanie oddać emocje i niuanse znaczeniowe, jak również elementy wojennej rzeczywistości $\mathrm{w}$ językach, w których nie istnieją precyzyjne słowa na ich określenie? ${ }^{29}$

Badaczka odpowiada jednoznacznie: ,jestem przekonana, że łatwiej jest opowiadać o doświadczeniach wojennych w języku, którego się wówczas używało, którym nazywało się tamten świat" ${ }^{\text {"30 }}$. Dlaczego zatem gros żydowskich pisarzy emigrantów wybrało trudniejszą drogę? Podjęło wyzwanie tłumaczenia doświadczeń, które same w sobie trudne były do przekazania? Czemu ani Rawicz, ani Langfus nie zdecydowali się na pisanie po polsku i thumaczenie tekstu? Czemu od razu decydowali się na francuski, który był językiem obcym, stanowił materię trudną w literackiej obróbce?

Można postawić hipotezę, że to właśnie owa „trudność” była dla obojga kluczowa. Mimo że tak różne obrali strategie zagnieżdżania się w języku francuskim, poszukiwali w nim, jak się wydaje, tego samego — przeszkody. Jak mówi w wywiadzie dla „Nouvelle Critique" Langfus:

Wcześniej pisałam po polsku - Pisałam z dużą łatwością. Jeśli nie znalazłam słowa, to nic, wymyślałam je. Byłam wolna, byłam u siebie, robiłam, co chciałam [...]. Tutaj [w języku francuskim - przyp. A. C.] to coś innego. Muszę być uważna, muszę szukać. Dlatego właśnie mój styl musi być bardziej precyzyjny. Nie mogę sobie pozwolić na nic innego ${ }^{31}$.

Bardziej dosadnie swoją praktykę pisarską komentuje Rawicz:

Dla mnie francuski był zawsze jak gospoda, czasem przyjazna, czasem wroga, czasem niewygodna. Był jak pożyczone ubranie trzepoczące na mojej skórze, na skórze mojej duszy. Nie mówię, że było to coś całkowicie negatywnego, z takiej ciągłej walki czasem wypływają korzyści [...]. To rodzaj ciągłego gwałtu, jak kapryśna kochanka, która pozwala ci na pewne erotyczne, nieklasyczne zabawy, ale nigdy nie stanie się twoją pełnoprawną żoną, żydowską matką, która nigdy cię nie opuści ${ }^{32}$.

$\mathrm{Z}$ obu tych wypowiedzi przebija jasny komunikat o ambiwalencji języka francuskiego; stwarza on nowe możliwości — otwiera drogę do mówienia, ale jednocześnie jest wrogi, trudny, wymaga nieustannej uwagi i ostrożności.

Czapski zarzuca Rawiczowi, choć zarzut ten można by tym bardziej postawić Annie Langfus, że jego francuski jest „straszliwie ugrzeczniony, zbyt akademicki”,33, i dodaje:

Ja sam, wtedy gdy piszę po polsku, to mogę się spierać o każdy przecinek, czy każde słowo będące moją kreacją. We francuskim chcę być dobrze wychowany, chcę pisać poprawnie i każda uwaga krytyka lub redaktora jest dla mnie święta. We francuskim jestem dobrym uczniem bez wyobraźni werbalnej ${ }^{34}$.

${ }^{29}$ Przypis.

${ }^{30}$ Dalej B. Engelking pisze: „Dlatego sądzę, że relacje opowiadane przez polskich ocalałych po polsku są bardziej wiarygodne, bliższe ich wewnętrznej prawdy, niż te opowiadane w innych językach"; B. Engelking, Zagłada i pamięć: doświadczenie Holocaustu i jego konsekwencje opisane na podstawie relacji autobiograficznych, Warszawa 2001, s. 237.

${ }^{31}$ Anna Langfus. Entretien, La Nouvelle Critique, czerwiec 1965 (niesygnowany); cyt. za: J.-Y. Potel, Les Disparitions, s. 177.

${ }^{32}$ P. Rawicz, Solitude, s. 73-75.

${ }^{33}$ K. Jeleński, P. Rawicz, J. Czapski i in., Pisarz na wygnaniu, s. 27.

${ }^{34}$ Tamże, s. 37. 
Rawicza być może brak tego typu wyobraźni nie dotyka, ale niezaprzeczalnie, mimo wykorzenienia pisarza, francuski ujmuje jego prozę w pewnego rodzaju ryzy, stanowi jej szkielet - stabilny trzon tekstu, co najwyraźniej widać w osobistych zapiskach, gdzie rama kakofonicznego tekstu utkana jest właśnie z francuszczyzny, poprawnej, można by rzec „wysuszonej” ${ }^{\text {"W }}$. U Langfus podobnie — choć jej proza ma całkiem inny charakter, to francuski trzyma jej świadectwo w ramach języka, jest ożywczy, jak twierdził Fickelson, a zarazem zmusza do nieustannej pracy nad słowem $^{36}$.

Jak pisze Elie Wiesel:

Francuski to język kartezjański, logiczny — Otóż to, co przeżyłem w dzieciństwie, w młodości, wszystkie moje wewnętrzne przygody, to było coś całkiem przeciwnego: byłem zanurzony w mistycyzmie. Jeśli jest język, który odrzuca mistycyzm, który mu się przeciwstawia, to jest to właśnie francuski. Transformować, przetłumaczyć na francuski pojęcia, koncepcje, odkrycia, sekrety mistycznego świata, to wyzwanie $[\ldots]^{37}$.

Przed takim samym wyzwaniem stanęli Langfus i Rawicz — oboje odrzucili w praktyce literackiej języki „mistyczne” — te, które miały w sobie cząstkę żydowskiego świata Lublina i Lwowa, infantylnej magii beztroskiego świata dzieciństwa.

Oboje przetłumaczyli swój świat, swoje traumy na język francuski — logiczny, poukładany, nieskażony doświadczeniem wojny. Dostrzec w tym można jednak konieczność postawienia opowieści przeszkody, uczynienia jej trudną. Pisanie po francusku nie pozwala bowiem na przypadkowość, dezynwolturę, więcej nawet, nakazuje oglądanie każdego słowa, rozpatrywanie każdej konotacji, odbiera wolność wyobraźni. Adorno opowiadał się za destrukcją, donkiszoterią językową, rozsadzaniem totalności języka, był przeciwny ,pełnym i zaokrąglonym” zbitkom językowym, w których „,szemrze niejako leniwy nurt zastałego języka, tymczasem pisarz powinien precyzyjnym wyrazem ustanawiać przeszkody "38. Pisanie po francusku to pisanie z przeszkodą, niemożnością poczucia się komfortowo w języku, to konieczność otrzepywaniem każdego słowa z popiołu, by dotrzeć do jego sensu, a przez to lepiej uchwycić istotę traumatycznego doświadczenia.

\section{LITERATURA}

T. W. Adorno, Dialektyka negatywna, przeł. K. Krzemieniowa, Warszawa 1987;

—, Minima moralia, przeł.. M. Łukasiewicz, Kraków 2009;

G. Agamben, Co zostaje z Auschwitz: archiwum i świadek, przeł. S. Królak, Warszawa 2008;

B. Engelking, Zagłada i pamięć: doświadczenie Holocaustu i jego konsekwencje opisane na podstawie relacji autobiograficznych, Warszawa 2001;

A. Ciarkowska, Pisanie „na zgliszczach” języka, Midrasz 2014 nr 5 (181), s. 47-52;

J. Czapski, K. Jeleński, P. Rawicz i in., Pisarz na wygnaniu a styl, Archiwum Emigracji. Studia — Szkice - Dokumenty 1999 z. 2, s. 23-37;

A. Dayan-Rosenman, Anna Langfus - pamięć/zapomnienie, przeł. A. Zachariewicz, Scriptores 2013 nr 34, s. 301-306;

35 „Sam skurcz muskułów w prawej ręce — przyprawia o 'wysuszenie' — oschłość - paraliż mózgu”; P. Rawicz, „Zeszyty”, rkp., s. 73. (archiwum prywatne Erica Veaux).

${ }^{36}$ J.-Y. Potel, Rozmowa z Maurice'em, s. 121.

${ }^{37}$ Le Point 10.01.2003, cyt. za : O. Rota, Choisirle français pour exprimer l'indicible. Elie Wiesel, http://iefr.univ-artois.fr/IMG/article_PDF/article_a46.pdf (dostęp: sierpień 2015).

${ }^{38}$ T. W. Adorno, Minima, s. 96. 
I. Kertész, Język na wygnaniu, przeł. E. Sobolewska, Warszawa 2004;

S. Kofman, Paroles suffoquées, Paryż 1986;

A. Langfus, Krzyku się nie wydrukuje, przeł. H. Abramowicz, Scriptores 2013 nr 34, s. 167-175;

Anna Langfus. Entretien, La Nouvelle Critique czerwiec 1965 (niesygnowany), s. 45-51;

C. Marlaux, Ostra - rozmowa z Annq Langfus, przeł. H. Abramowicz, Scriptores 2013 nr 34, s. 91-95;

H. Mitgang, Profiles: Imprint. Helen Wolff, The New Yorker, 2.09.1982, 42-73;

J.-Y. Potel, Kalendarium życia i twórczości Anny Langfus (1920-1966), przeł. A. Zachariewicz, Scriptores 2013 nr 34, s. 17-54;

J.-Y. Potel, Les Disparitions d'Anna Langfus, Paryż 2014;

-, Rozmowa z Maurice'em Fickelsonem, przeł. H. Abramowicz, Scriptores 2012 nr 34, s. 120-132;

P. Rawicz, Solitude Juive dans la création litteraire, [w:] Solitude d'Israël: données et débats / $X V^{e}$ Colloque d'intellectuels juifs de langue française ; organisé par la Section française $d u$ Congrès juif mondial, red. J. Halpérin, G. Levitte, Paryż 1975;

—, „Zeszyty”, rkp. (archiwum prywatne Erica Veaux);

—, Préface, [w:] E. Sevela, Légendes de la rue des invalides, Paris 1992;

O. Rota, Choisirle français pour exprimer l'indicible. Elie Wiesel, http://iefr.univartois.fr/IMG/article PDF/article a46.pdf (dostęp: sierpień 2015);

P. Sadkowski, Proza Piotra Rawicza jako przyktad pisarstwa francusko-żydowskiego w świetle (post)kafkowskich koncepcji ,,literatury mniejszej” i zjawiska „,nadświadomości językowej”, [w:] „Literatury mniejsze” Europy romańskiej, red. M. Loba, B. Luczak, A. Gregori, Poznań 2012, s. 77-86;

A. Ubertowska, Świadectwo, trauma, głos. Literackie reprezentacje Holocaustu, Kraków 2007;

Z. Waxman, Writing the Holocaust: identity, testimony, representation, Londyn 2008.

\section{LANGUAGE AS A CHALLENGE. ANNA LANGFUS'S AND PIOTR RAWICZ'S WRITING STRATEGIES}

The article analyses two Holocaust novels that have formed, to a large extent, the French memory of the Shoah: Le sang du ciel by Piotr Rawicz and Le Sel et le Souffre by Anna Langfus. Both Rawicz and Langfus, who came from families of assimilated Jews, were born in Poland where they went through the hell of the Second World War. In 1946 they decided to emigrate to France and then, in the 1960s, they started to write in French. Despite these similarities, each of them had a different method of functioning within the new language. Langfus decided to use "linguistic mimicry" and she became almost completely French-speaking, whereas Rawicz professed "linguistic uprootment," going beyond the French language. The article discusses the reasons and consequences of undertaking the "challenge" of writing directly in French, and analyses chosen creative strategies and their impact on the final concept of the two novels.

KEYWORDS: French literature; multilingualism; emigration; Jewish literature; identity; Holocaust literature; Anna Langfus; Piotr Rawicz. 